\title{
学術· 技術論文
}

\section{急傾斜山林地用実大歩行ロボットの開発}

\author{
妻 木 俊 道*1 小林 洋 司*2 中 野 栄 二*3 \\ 内 山 研 史 ${ }^{* 4}$ 玉 田守*5
}

\section{Development of a Practically Scaled Walking Robot for Steep Terrain of Forestry Ground}

\author{
Toshimichi Tsumaki*1, Hiroshi Kobayashi*2, Eiji Nakano*3, \\ Kenji Uchiyama*4 and Mamoru Tamada*5
}

\begin{abstract}
We introduce a large scaled 6 legged walking machine. It was developed to realize a solid and reliable walking vehicle for practical uses in forestry steep terrain with spread mechanical elements those used in usual construction machines. It weighs about $4,000[\mathrm{~kg}]$ with aluminum structure. Owing to a mounted diesel engine of output $11[\mathrm{~kW}]$ and hydraulic drive systems, it can walk around on a soft soil terrain and climb the steep slope of inclination up to about 30 [deg], and walk along contour line of lateral inclination up to about 40 [deg]. Finally it walked and worked well, despite it was tested on severe steep terrain where a lot of shrubs and stumps exist.
\end{abstract}

Key Words: Walk, 6 legged, Terrain, Forestry, GDA, Soft Landing, Practical, Hydraulic

\section{1. は じめに}

山林地 , 危険地帯等での機械化は進んでいるとは言えない.中 でも，急傾斜自然地形や不整地での機械化は遅れている.主因 は, 専用の作業装置が大型，あるいは重く，弚れらを自在に搬 送し，弚の活動範囲を拡げる，実用的で，高い耐環境性，信頼 性，自立性 (制御装置, 動力源の搭載) を有し，適度なコスト で運用できる適切な移動機械，言わば walking platform が実 用化されていないことが挙げられる．弚のような移動機械とし て各種歩行機械が試作された [1] [2] .

筆者は, シンプルな機構要素の組み合わせと，簡単な制御に より急傾斜不整地で移動できる独自の脚式歩行原理実証機を考 案，試作し，弚の方式の妥当性を報告した [3] [4].

光の歩行機械の機構構成を Fig. 1 に示す. 弚れに沿った原理 実証機が，屋外の土の丘を移動している樣子をFig. 2 に示す． 弚の原理実証機では以下の性能を実現した .

\footnotetext{
原稿受付 2008 年 10 月 27 日

*1三菱重工業 (株)

$* 2$ 東京大学

$* 3$ 千葉工業大学

*4 (社) 林業機械化協会

${ }^{* 5}$ (有) イーストドライブ

${ }^{* 1}$ Mitsubishi Heavy Industries, co. ltd.

${ }^{* 2}$ The University of Tokyo

${ }^{* 3}$ Chiba Institute of Technology

${ }^{* 4}$ Forestry Mechanization Society

${ }^{* 5}$ East Drive. Inc.

ロ 本論文は有用性で評価されました 。
}

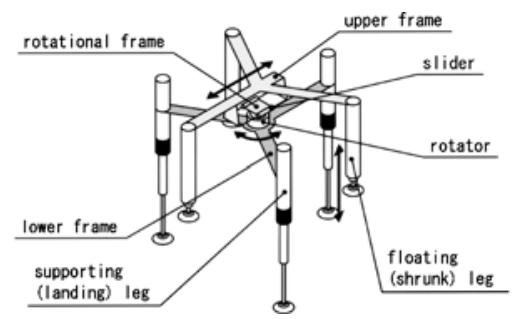

Fig. 1 Principal structure of the model

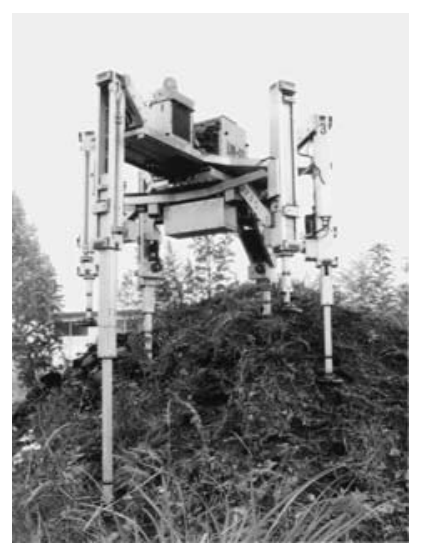

Fig. 2 Machine that proved principle of walking (Development had completed in 1991)

(1) 約 $35^{\circ}$ の斜面，階段を登降坂できる.

(2) 軟らかい土裹不整地を踏破できる

(3) $1[\mathrm{~m}]$ 程度の高さの障害を乗り越えることができる． 
今回，育林等を行っている山林急傾斜地において，歩行移動， 作業ができる，上記原理実証機と同じ方式 (Fig. 1) の実大移動 機械を開発し，実際の急傾斜不整地で試験し，性能を確認した． 本機械の開発が完了したのは,やや古いが, ほかにも，6 脚 式等で大型の歩行機械の開発例は見られる $[5] \sim[8]$. 乥れらと異 なる本機械 [9] にも十分な特長があり，報告する．

\section{2. 歩 行 原理}

\section{1 歩行移動機構}

Fig. 1のように，伸縮自在な脚が upper frame と lower frame に光れ光れ垂直に 3 本ずつ，三角形状配置で取り付けられてい る.なお，全 6 脚とも同構造である . lower frame 上面には rotator を介して rotational frame が取り付けられている.さら に rotational frame 上面にはリニアベアリングと駆動機構が取 り付けられており，upper frame をスライド駆動できる . 結局， lower frame と upper frame は, rotational frame を介して相 対的にスライド, 旋回できる . 弚の 2 軸の極座標系で制御でき る水平動作と, 二つのフレームに垂直に取り付けられた各 3 脚 の降下着地・引き上げの繰り返しの計 8 軸により歩行移動を行 う.なお，方向転換はもちろんできるが，力二歩き的な横への 水平スライド移動はできない .

Fig. 3 に本機械の歩行シーケンスを示す . 6 脚のうち lower frameに取り付けられた 3 脚と, upper frameに取り付けられ た 3 脚を交互に踏み替えて歩行移動を行う. 着地シーケンス途 中の 3 脚弚れ光れは, 斜面不整地に着地する際，おのおの任意 の高さの地点に着地・停止し, 光の 3 脚で斜面, 不整地に適応 する.

\section{2 本機械の基本構造と特徵}

本機械は脚構造を中心に以下の特徵を有する .

(1)作動軸に GDA (Gravitationally Decoupled Actuation)

(Fig. 4 (2)) [10] [11] を活用しており，水平移動中，自重支

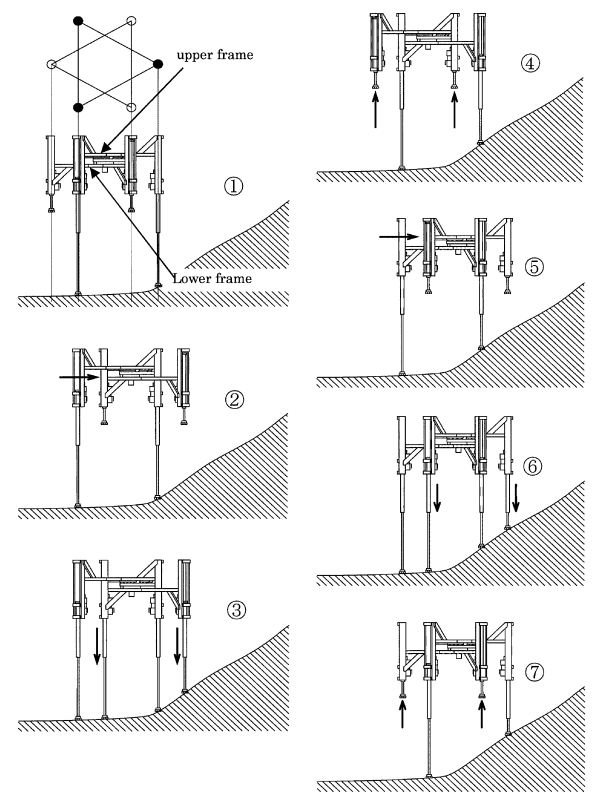

Fig. 3 Sequence of the walking principle
持を行うには, 基本的には自重支持脚の (鉛直方向の) 伸縮を 機械的にロックするだけでよい. 水平な場所での姿勢高を変 えない歩行では自重支持エネルギーは理論的にはゼロとなる． (2)GDA により水平移動と鉛直移動・支持が分離され，脚は基 本的には伸縮方向の荷重を専ら受けるので，単純化できる．

(3)水平移動は, 自重支持 3 脚間の位置関係および光の着地状況 は変わることなく, 二つの 3 脚群を取り付けたフレーム間の スライド・旋回の 2 軸のみで行うので, 脚相互間に加わる無 理な力や, 地面に対する滑りを考慮する必要がない .

(4)移動を停止して作業を行う場合 , 全 6 脚を着地させることで， 搭載作業装置にとって，よく安定したプラットホームとなる。 以上の効果として，(1)は高エネルギー効率化，(2)軽量化， (3)は制御と炎のシステムの簡略化に, 光して(4)は運用上の安全 化に有効である . 駆動軸のすべてが建設機械 , 特にクレーン車 等で用いられているスライド動作と水平旋回動作のみであるこ とから，既存成熟機械技術により一般建設機械並みのコストで 大型実用化させ，普及させることか期待できる．

\section{3. 運用と目標}

\section{1 本機械の運用}

本機械では, 人力では難儀する, Fig. 5 のようなフィールド を移動・踏破できる必要がある.

(1)平均斜度は $20^{\circ} \sim 30^{\circ}$ であるが, 部分的には $35^{\circ}$ を超える .

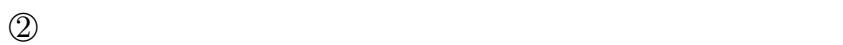
(3)切り株，大岩を踏んでも安定で，植樹幼木をまたぎ超えできる． 人力の場合と同樣，作業効率を良くするため，自ずと Fig. 6 のように, 上下が少ない等高線沿いに移動しながら行う．关の ため，歩行移動しやすく，作業効率も良く，機械の位置エネル ギーの高低も少ないのて効率的に運用できる．ある等高線沿い の作業完了後, 光の上か下の線上に移り，作業を続ける .

乥の際，等高線間移動は, 移動方向に対してカ二歩き的な横

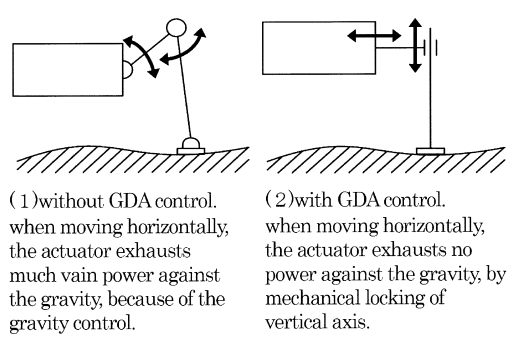

Fig. 4 Ways of sustaining the weight

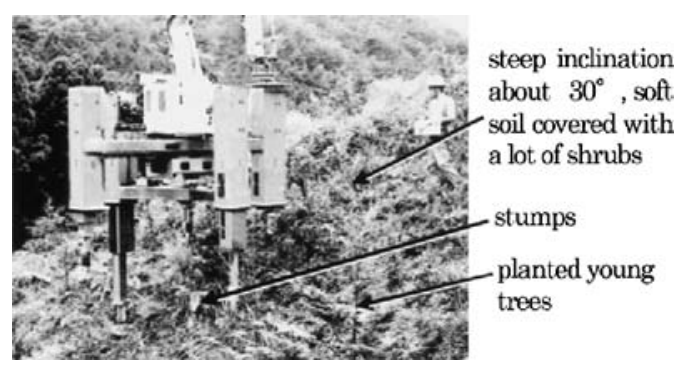

Fig. 5 Environment of field to walk 


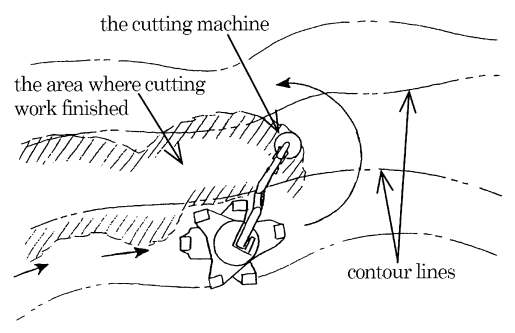

Fig. 6 A moving pattern of the machine at a forestry steep terrain walking along the contour line. Walking and cutting work in the shrubs are alternately done

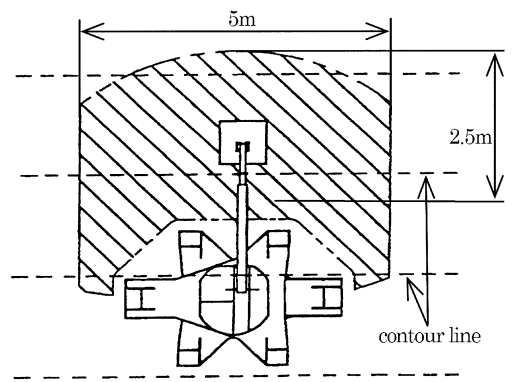

Fig. 7 Cutting area of one time. Aftre the walking is finished and all 6 legs are standed, the cutting work is started

スライドはできず (2.1 節)，Fig. 6 のように旋回 (U ターン) させる点が, 操作上やや面倒である .

作業は, 移動停止後, 全 6 脚で立って安定した状態で , 作業 アームの先端に取り付けられている刈払い機で行う．刚払い機 以外の作業装置による他の作業ももちろん可能である .

その際の刚払い範囲は, おおむね Fig. 7 の範囲である . 作業 アームが地面に到達が容易で, 安全上からも山側のみの作業を 行う.

乥こで作業を完了すると，等高線方向に移動して，次のエリ アに移動する (1 区間は Fig. 7 に示す約 $5[\mathrm{~m}]$ となる) . なお， 本機械では, 安全上の配慮もあり，移動と作業は同時には行わ ない。

\section{2 開発目標}

(1) 急傾斜山林地形の分析では, Fig. 5 の地形のように , 平 均斜度 $20^{\circ} \sim 30^{\circ}$ が多いが, 部分的には $35^{\circ}$ 以上に達する。

光のため, $30^{\circ}$ 程度の登降坂能力を有し，局所的には歩幅を 短くして $30^{\circ}$ 強の斜面を移動できることとする．

Fig. 8 を見て考えれば, 脚長 (鉛直ストローク) は同じまま で歩幅を短くすることで, 登降坂できる斜面角度を増大できる． ただし，弚の分，移動速度は減じる。

(2) オペレータが歩行動作を細かく意識しない簡単な無線操 縦方式を開発する (Fig. 2 の原理実証機 [4] で開発した方式の適 用を行う).

（3）屋外自然地形，自然環境下で使える全天候性を付与する.

（4）動力，歩行制御装置をすべて搭載した自立型とする.

(5) $1.5[\mathrm{~m}]$ 程度以上の障害物を乗り越え（またぎ越え）で きる .

（6）狭い林道を通り易いよう，普通自動車免許で運転できる ワイド荷台の $4[\mathrm{t}]$ トラック (当時) で搬送できるようにした。

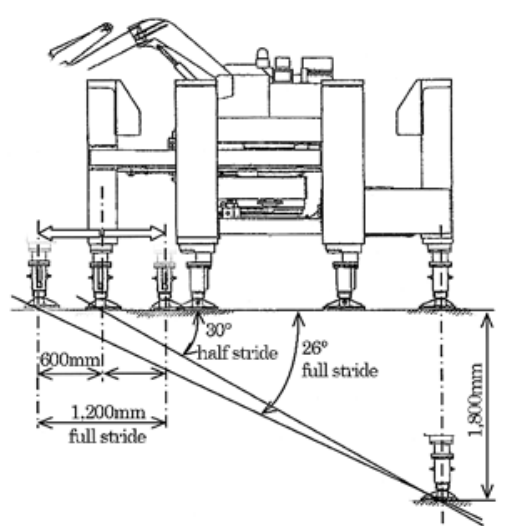

Fig. 8 A climbable slope angle varies with the length of the stride (side view)

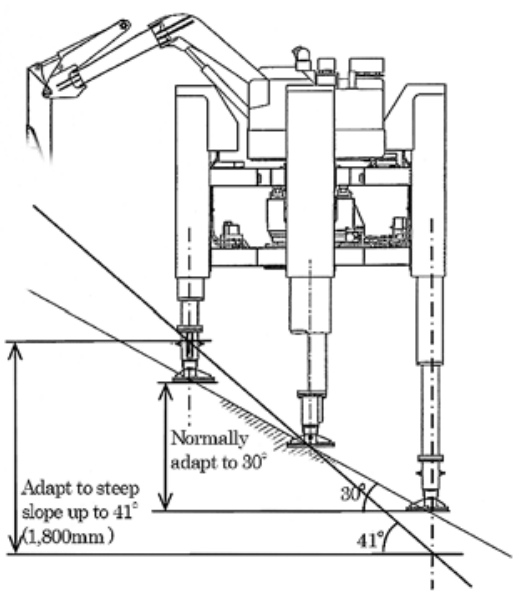

Fig. 9 Adapting to steep slope of about $40^{\circ}$ during walking along a contour line (frontal or rear view)

道路運送車両の保安基準 [12] での荷台最大外幅は $2.5[\mathrm{~m}]$ まで， 路面からの最高搭載部の高さは $3.8[\mathrm{~m}]$ 未満の条件で搬送でき ることと定められている．なお，乥れを若干超える部分がある が, 弚れらは簡単に外して運ぶことができる。

(7) 開発期間短縮等のため, エンジン動力部, 駆動用油圧ポ ンプ, 光して作業用アーム (ブーム) には, 弚れらをまとめて 備えている市販ミニショベルの足回りを外したものを流用する こととする .

(8) 今回は歩行機械としての開発に集中し，刏払いのための アームの自動化等は行わない，なお，本論文では述べないが， (7) のミニショベルの作業用アーム (ブーム) を, 自動化はし ていないが, 適切な機構の専用開発アームに換装して実地試験 を行い，作業効率の向上を確認している .

（9）転倒すると，危険であるのはもちろん，復旧が困難であ るので, 転倒させない運動制御機能を重点的に開発する .

\section{3 移動機構の検討}

まず，実際の運用について，現場視察により，潅木や，植樹 幼木等をまたいで移動するために，本体が越えられる高さとし て, 人の背の高さ程度 $(1.5[\mathrm{~m}]$ 以上) が必要と考えた . 進行方 向に登降坂する際の側面图を Fig. 8 に示す. 
Table 1 Principal ability of the machine

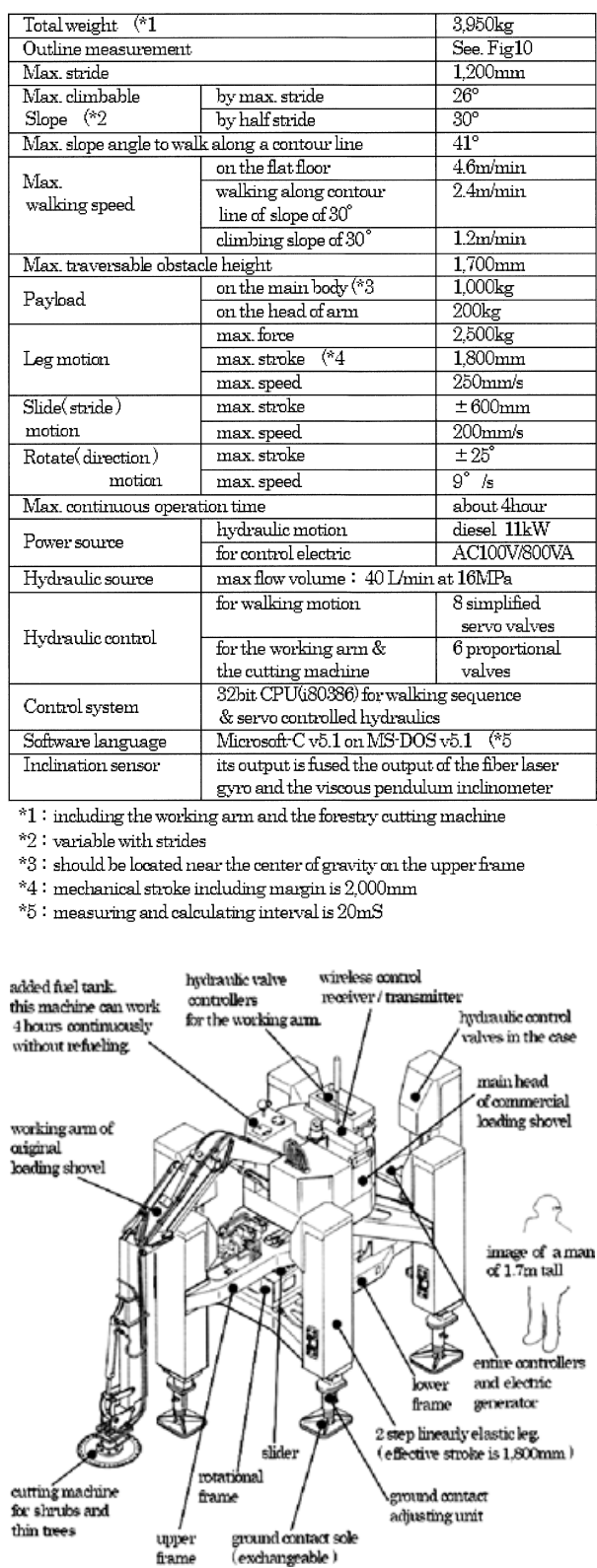

Fig. 10 Surface structure of the machine

そこに示す通り，歩幅によって平均登坂角は変化する。 歩幅は最大 $1,200[\mathrm{~mm}]$ であるが，光の際の平均登坂角は約 $26^{\circ}$ である . 歩幅を半分にすると , 約 $30^{\circ}$ の登坂が可能となる . このことで局所的急斜面には，歩幅を減らして対応できる． 一方，林業用機械としての移動は，Fig. 6 の通りであるが， 本機械では脚配置が，全長に対し全幅が短い (Fig. 8 と Fig. 9 は, 同じ縮尺で載せている) . したがって, 前後進での登降坂 角 (Fig. 8) より，等高線方向移動時の横斜面傾斜への対応角 (Fig. 9) が大きく，41ㄷ好適である.

以上の考慮で, 部分的には $40^{\circ}$ にも及心斜面に対応可能とな るよう，脚の有効ストロークを $1,800[\mathrm{~mm}]$ とした .

なお，上記で，等高線方向移動途中での対応角は $41^{\circ}$ (Fig. 9) で，乥れに直交する斜面登坂方向では $30^{\circ}$ (Fig. 8) では前者が

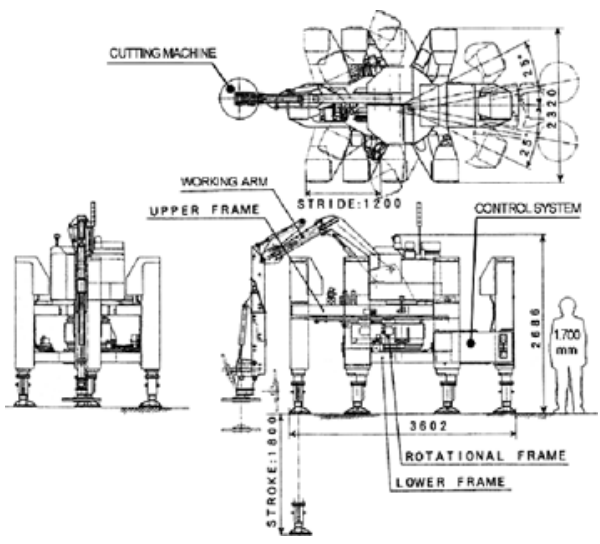

Fig. 11 Outline drawing of the machine

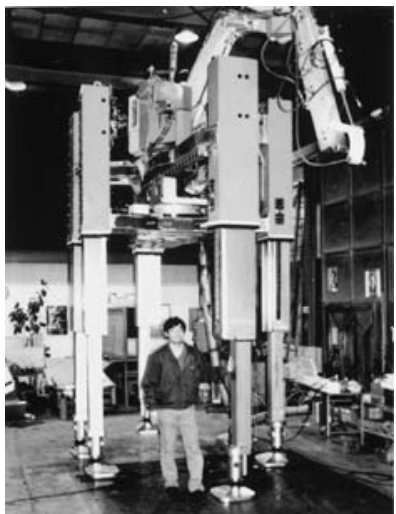

Fig. 12 Standing posture with all legs fully extended. The top of the machine is about $4.5[\mathrm{~m}]$ tall

一見無意味のようにも解釈されるが， $40^{\circ}$ は，局部的な最大傾 斜角であり， $30^{\circ}$ 程度の場所も，光れ以下の場所も多く，兴の ような一般的な山林地形で, 主な移動となる Fig. 6 の等高線移 動を $41^{\circ}$ の斜面迄対応できることで, 十分な対応ができる．

\section{4 開発仕様の決定}

以上から決まった本機械の諸元を Table 1 に, 基本構造外観 を Fig. 10 に示す. 外観 3 面图を Fig. 11 に示す.最も背を低 くして, 歩幅中央の状態である. Fig. 12 は完成直後の最高姿 勢状態の本機械である (刚払い機は未装着).

$$
\text { 4. 機 構 }
$$

\section{1 全体概要}

Fig. 10 に示す , おのおの 3 本の脚を取り付けている二つの本 体フレームはアルミニウム中空溶接構造で, 溶接性, 耐蝕性を 考慮し，A5083 材を使用した．八ニカム板の強度原理に似た， 間隔をあけた 2 枚の板材により高強度，高剛性を得ている．

脚もアルミ構造で, 取付部以外はすべて同構造である。

3.2 節 $(7)$ に沿って，本体上部には，市販ミニショベルの足 回りを外したものを載せている.内部にはディーゼル機関て駆 動されるギヤポンプがあり，本機械全体に油圧を供給する．

作業アームもミニショベルのアーム (ブーム) を流用した .

作業アーム先端には, 図のような専用の刈払い機が取り付け られている (Fig. 10) . 外周径 $610[\mathrm{~mm}]$ の二重反転刃バリカン 
構造で, 比較的安全に, 直径数 $[\mathrm{cm}]$ 程度の潅木類を高速に刈払 うことができる．質量約 $60[\mathrm{~kg}]$ （(社）林業機械化協会よりの 貸与品)．なお，作業アーム先端には，より大きい作業機械（最 大質量約 $200[\mathrm{~kg}]$ ）を取り付けても運用できるよう考慮されて いる。

下段フレーム (lower frame) 後部の拡張室内 (Fig.11 の 'CONTROL SYSTEM' 部) に, コンピュータ, サーボ弁アン プ, 乥して強制空冷コンパートメント内には, 制御装置や油圧 バルブ制御・駆動用の市販発動発電機が搭載されている。

ミニショベルヘッド，発電機は，約 4 時間の連続無補給運転 ができるよう, 燃料タンクを増大改造した .

\section{2 脚構造}

脚構造を Fig. 13 に示す. A5083 アルミによる outer leg frame, mid leg frame, inner leg frame の三つで構成されて いる.

フレーム間はリニアガイドにより相互に直進スライドする . 本 機械本体フレームに固定される outer leg frame に対し ,Fig. 14 のように, mid leg frame が drive cylinder によって長さ : $L$ だ け伸長されると synchronous chain によって , inner leg frame は, outer leg frame に対し, 倍速, 倍長で伸縮する.最短長が 短い脚でもストロークを大きくできる .

脚の有効ストロークは $1,800[\mathrm{~mm}]$ であるが, 両端に各 $100[\mathrm{~mm}]$ のマージンを取っており , 2,000 [mm] で作られてい る . $1,800[\mathrm{~mm}]$ を超えてマージンの $100[\mathrm{~mm}]$ に入って伸縮し ようとすると, ソフトウェア, 油圧ハードウェアの両面から安 全上, 動きが拘束される .

脚の長さは, 磁気抵抗式のアナログ出カリニアセンサを用い,

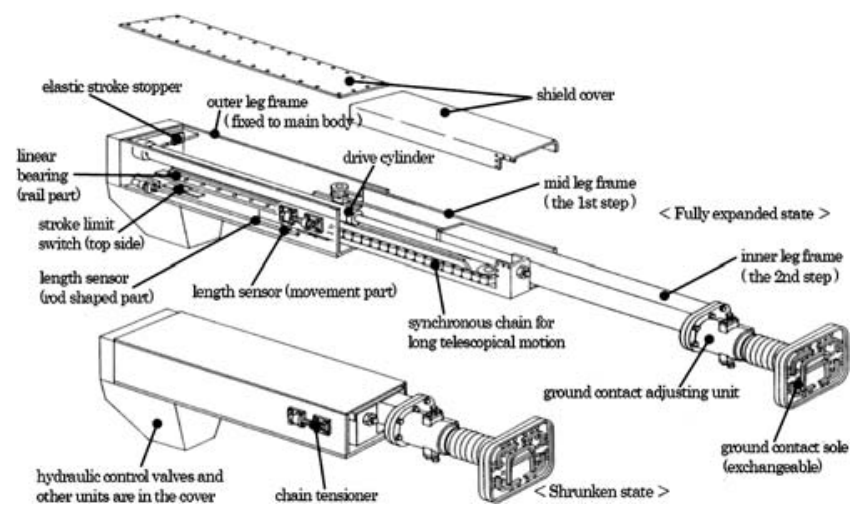

Fig. 13 Structure of expandable leg

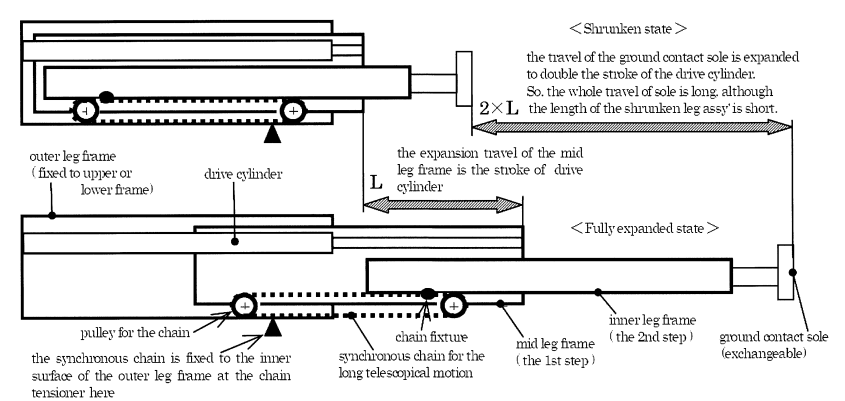

Fig. 14 Principle movement of a expandable leg mid leg frame の伸びを測長し，元れを倍にして脚長とする . ground contact adjusting unit には後述 (Fig. 19) の脚先接 地検出およひ軟着地用機構が備えられている . ground contact sole は交換式で, 後述の方式の比較検証を実施した (4.5 節) .

\section{3 脚の強度}

脚の強度を決める場合, 垂直 (伸縮) 方向耐荷重と, 脚先接 地部に加わる水平方向耐荷重を考える (Fig. 15).

（1）垂直 (伸縮) 方向耐荷重

(1)歩行中に前部支持脚が岩や切株の端等の不安定部に着地した とする (Fig. 16) .

(2)弚こで滑り落ち，機械最前部の地上 $600[\mathrm{~mm}]$ にある浮脚の 脚先が，地面に衝撃的に着地した場合 (Fig. 17).

その 1 脚への最大荷重が, シミュレーションで瞬時約 $80,000[\mathrm{~N}]$ と見積もられた .なお，固い土壤を想定した（厳し 目に設定) .これにより，保安部品の synchronous chain の引 張り強さは余裕を見込んで, $140,000[\mathrm{~N}]$ (安全率 1.75) とした. シリンダにはリリーフ弁を設け, 衝撃による油圧系の損傷も防

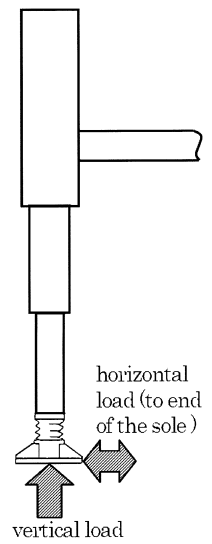

Fig. 15 Load to the foot sole

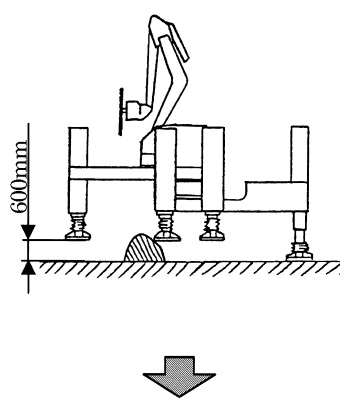

Fig. 16 Standing unstably for instance a sole is on the rock or stump

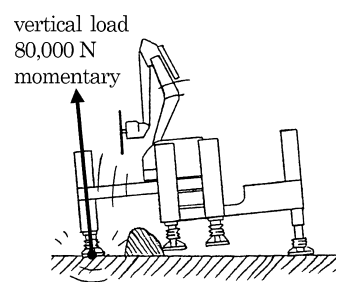

Fig. 17 Impact shock from the ground by collission by pitch forward 


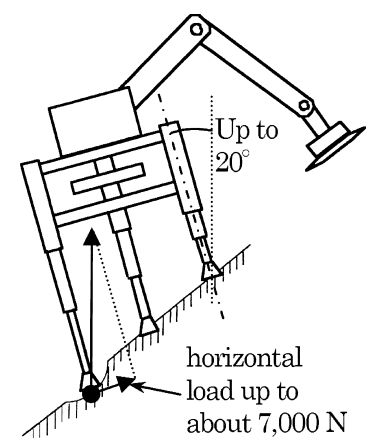

Fig. 18 Big horizontal force joins to the sole of leg when the machine inclines

いでいる

（2）水平方向耐荷重

(1) $30^{\circ}$ の斜面を等高線方向に移動中 (Fig. 9) に, 最も伸びた 谷側の脚がゆっくり沈下し, 全体が $20^{\circ}$ (作業アームを山側 に向けて安全側にある際の概略転倒限界角) 傾いた際, 最も 大きな荷重が加わる谷川の脚先への水平荷重は, 約 $7,000[\mathrm{~N}]$ となる (Fig. 18) .

(2) の傾いた状態から水平に復帰しようとする際 , 各脚先接地部 間の水平距離は狭まろうとし, 脚先接地部は, 土壤から水平 反力を受ける.膨軟土壤では最大静止摩擦係数換算で約 0.7 , 脚先水平荷重は最大約 9,200 [N] と推定した . 以上 (1), (2) か ら脚先水平耐荷重を, 脚が最も伸びた状態で, $10,000[\mathrm{~N}]$ と し，設計を行った．各種試験を行ったが問題はなかった .

4.4 歩行速度の向上と脚の軟着地方式

歩行速度を高める場合，脚の伸縮速度を速めればよい．しか し, 単純な高速化では着地時の即停止は困難で, 衝撃を伴い, 急 斜面等で歩行安定性等が悪化する. 光のため, 軟着地機能を考 案, 装備した. 非接触センサ (レーザ, 超音波等) を取り付け て地面までを測距し，軟着地させる方法もあるが, 潅木や草の 多い山林地, 泥ねい地では信頼性, 耐環境性から実用にはなら ない。

脚先にコンプライアンス特性を設定して, 着地衝撃を吸収す る事例もあり, 接地部センサが不要であるなど優れる [13] .

本機械では，着地は脚の鉛直上下で行い，別方式で実現できた . 原理実証機 (Fig. 2) [4] で良好であった制御が簡単な，Fig. 19 に示す構成, シーケンスで作動する簡単なスライド式脚先機構 により, 軟着地, 着地安全確認を実現している .

Fig. 19 の (1) の脚先が浮いている状態では, 最高速で降ろす . (2) で, 垂直方向にフリースライドする脚先部が, 荷重を受け ない状態で, 着地し, スイッチ B か離れ,「着地完了間近」を 検地すると，微速に減じ，(3)で脚先が，本体を支えられるだけ の荷重を確認後, 軟着地が完了する (Fig. 20) (実用新案取得 済 [14]) .

なお, 軟土壤等で, 支えられる荷重が十分とならない場合, 十分 となるまで脚を踏み込ませる「踏み固め」を行う (Fig. 20 (4)) .

さらに, 水平旋回・スライドについても速度を上げたいが, 起 動・停止時に水平方向に慣性力が働き，摇れ等を招く.Fig. 21 のように, 姿勢高 (支持脚 3 脚の長さの平均值で代表) に応じ て, 水平旋回・スライドの加速度 - 減速加速度, 乥して最高速

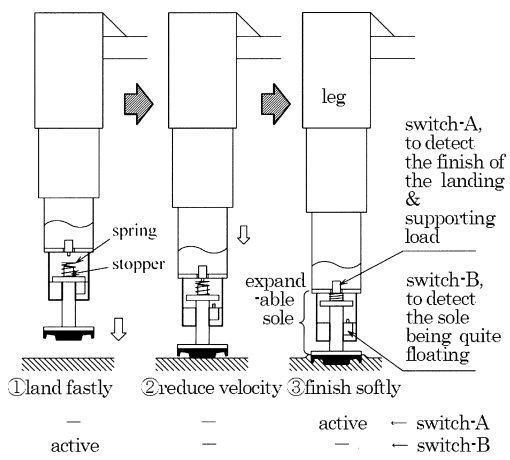

Fig. 19 Mechanism and sequence of soft landing of a leg

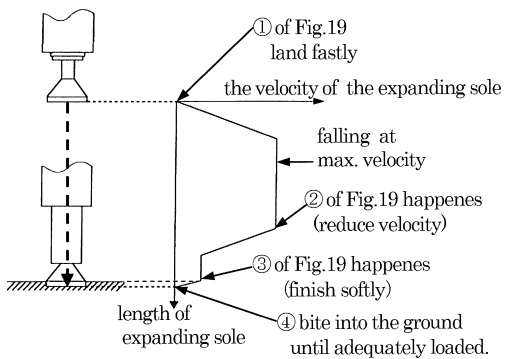

Fig. 20 Velocity variation of a soft landing sequence

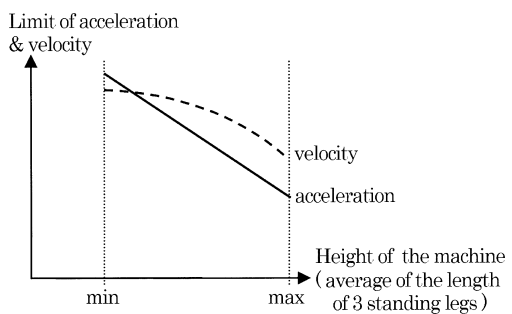

Fig. 21 The maximum of acceleration and velocity are reduced according to the height of the machine

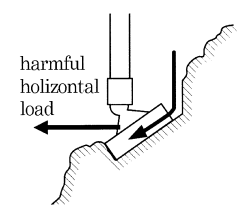

(1)Landing with flexibly the slippery slope surface, the sole pad gets the horizontal load because of a landslide. leaning jointed sole pad. On

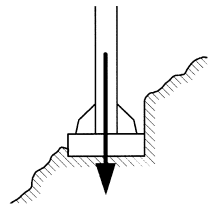

(2)Landing with no leaning fixed sole pad. The sole lands vertically and stables without horizontal loads, even the ground is slippery.
Fig. 22 Difference of types of the landing sole pad

度を適切に抑制し，歩行安定性を高めた（特許取得済 [15]）。

また，本機械は本体を水平に保った上で移動，作業を行うの で, 安定した移動プラットホームとなるが, 歩行時に, 地面の 沈み込み, 地面の地滑り等により, 突発的にも傾斜が生じ得る .

弚れを傾斜計 (レーザジャイロ出力と粘性振り子傾斜計出力 を融合したもの) により常時モニタし，傾斜角が一定を超える と，最優先で傾斜補正を行う（参考：6.2 節 (3)).

\section{5 脚先接地部の検討}

斜面土壤においては, 脚先の接地部分の構造が接地安定性に 影響する . Fig. 22 (1) のような傾斜に適応するとされる首振り 
式がよく見受けられるが，山林地の膨軟土猿においては土壤表 層が地滑りし，不安定となることが確認された .

また, 首振り部角度か変化すると, 脚先の位置の水平成分が 変化し, 脚先に無理な水平力か加わり好ましくない .

特に膨軟土壌では, 単純な Fig. 22 (2) のような足首固定式が， しっかりと踏み固め, 脚先への水平荷重は発生せず安定した .

筆者らは，実地膨軟土蚺斜面で自分の足首を Fig. 22 の 2 態の ように変えて歩いたが, (2) 相当のほうが有意に安定感があった。

スキーで斜滑降で滑る際，足首を無力にしてスキー板を斜面 にベタで沿わせた場合と，斜面に対しスキー板を水平に保持し てエッジを立てた場合では，後者が有効であることと似ている． なお，造成した軟土の丘で，本機械に取り付け，着地させた 2 種の脚先接地パッドの樣子を Fig. 23〜25 に示す.

4.6 操作系

(1) 歩行移動機構

基本歩行移動は , 2 本のジョイスティックと一つのボタンによ

り Fig. 26 のように歩幅 (stride), 方向 (direction), 乥して全

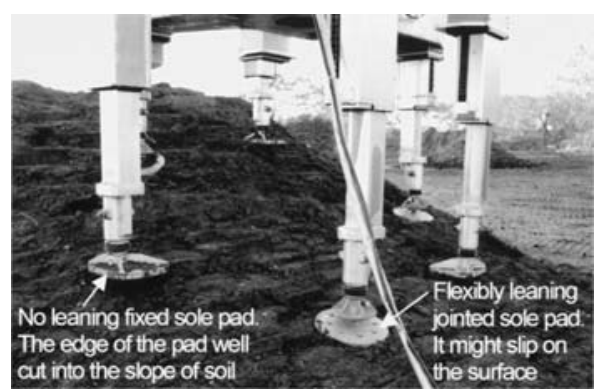

Fig. 23 Two different type sole pads

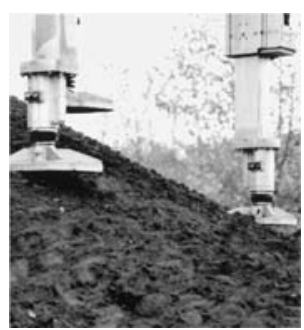

Fig. 24 No leaning fixed sole pad (adequately loaded)

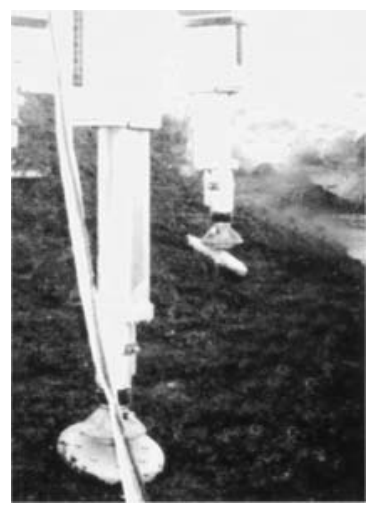

Fig. 25 Flexibly leaning jointed sole pad. Max. bobbing angle is $\pm 30^{\circ}$ all around
体高 (height) が操作される. 各脚の接地 , ホールドは Fig. 19 の機構により制御され，3 脚同時の支持脚踏み替え動作は, 一 つのボタンを押すことで自動実行され, シーケンス操作をオぺ レータは意識せずともよく, 非常に簡単に操作できる . 各支持 脚の長さも，全体高の指示に沿いつつ傾斜計により本体を水平 に保つように制御されるため，これもオペレータは意識しない．

\section{(2) 作業アーム機構}

本機械では， 3.1 節の最後に記した通り，安全上, 移動と作業 は同時には行わない . 作業は, 全 6 脚を着地させて, 安定に静 止した上で行う．弚のため，作業時の操作装置は，(1) の歩行 移動機構と同じ操作器を排他的に兼用する . 作業アームの自由 度は 5 (刈払い機は除く) であり，Fig. 27 の割り当てで操作 する 。

\section{(3) 操縦装置}

以上，(1)，(2) の通常歩行/作業の操作に加え, 各個の作 動軸の調整等手動操作，およびエンジンの起動/停止/回転数 調整等および，油圧の調整ができ，一方，機械本体の各種状態 (各脚の接地状態, 油圧, 油温, 水温, エンジン回転数等の数值) をリアルタイムでモニタできる可搬式の双方向無線式操作・表 示器を作った (Fig. 28).

スペクトラム拡散 (SS : Spectrum Spread) 式無線モデムを

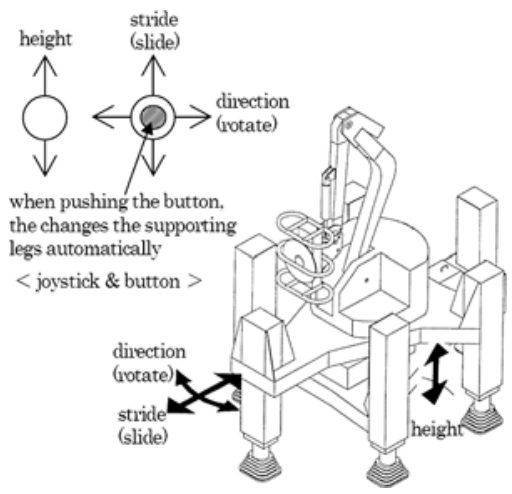

Fig. 26 Usual walking operation

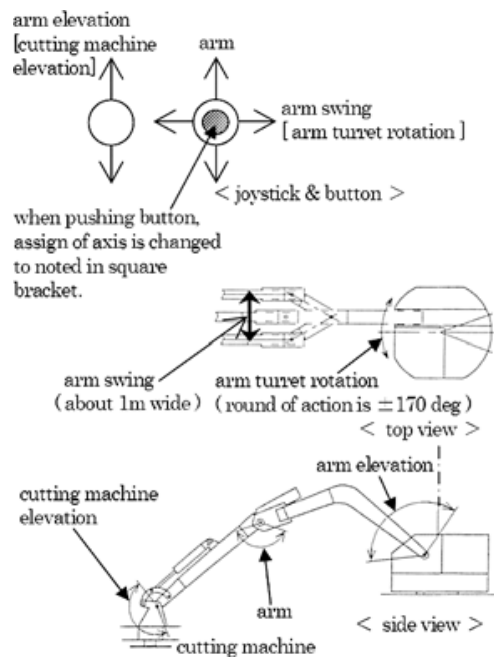

Fig. 27 Working arm operation 


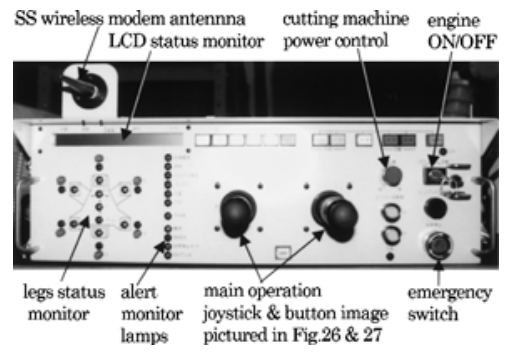

Fig. 28 Wireless operation control \& monitor box

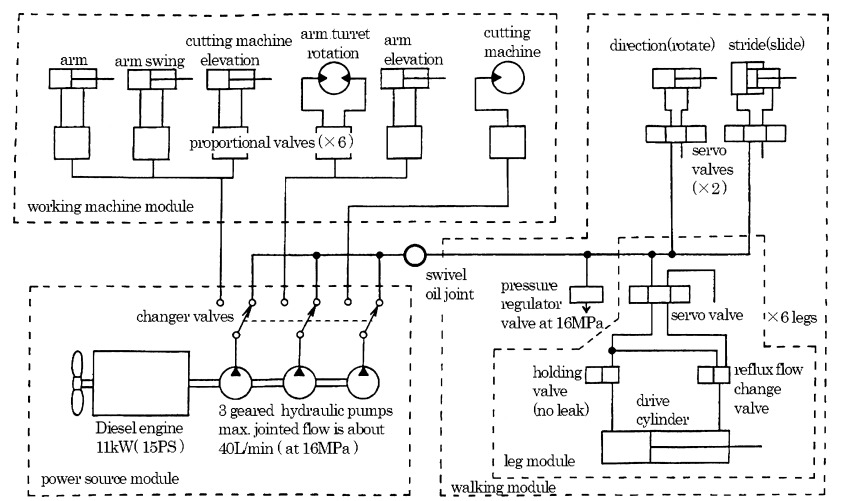

Fig. 29 Outline of whole hydraulic drive system

用い, 通信エラーが連続したり，電波が届かない場合，機械本 体側で, 安全な方向に退避行動を取り，停止・待機状態となる。 本操縦装置はストラップで首にかけて使用する .

\section{5. 動力・制 御 系}

\section{1 動力系}

本機械は油圧駆動式であり [16]，ディーゼルエンジンで油圧 ポンプを回し，弚の油力を各動作軸用のサーボ弁 (歩行系 8 軸)， および比例弁 (作業系 6 軸) を制御して動作する. 光の概略全 体構成を Fig. 29 に示す.

\section{2 脚油圧駆動采}

脚は, drive cylinder と乥れを倍長する構成で伸縮される (Fig. 14) . drive cylinder は, Fig. 30 では, head side に油を 圧入, rod side から排出し, rod を押し出し, 脚を伸長する .こ れは，支持脚を強力に伸長する場合か， head side の圧を維持 しつつ油の流れを逆転して支持脚を縮める場合である .Fig. 31 では, head side に油を圧入した上, rod side から戻される油 を head side に加え戻す (reflux : 還流) ことで, 発生力は減る が，Fig. 30 の場合と同じ油量入力で，より高速に伸長できる .

Fig. 19 の (1) のように脚先が浮いている際の無負荷高速伸長 に適する . 脚を引き上げる際は, Fig. 30 の逆流であるが , 油が 押す面積がロッド断面積分小さいため，速く引き上げられる．

なお, 安定して立ち止っている際は, drive cylinder の head side を圧を保持したまま閉じればよく, 姿勢変化の必要がない 限り，エネルギー消費は 0 となる (弁の電源切て閉じる) . これ は 2.2 節 (1)の，効率を高める原理に沿ったものである .

ノーリークをうたった弁が市販されており，乥れを holding valveに使用して，同じ姿勢を保持できた .

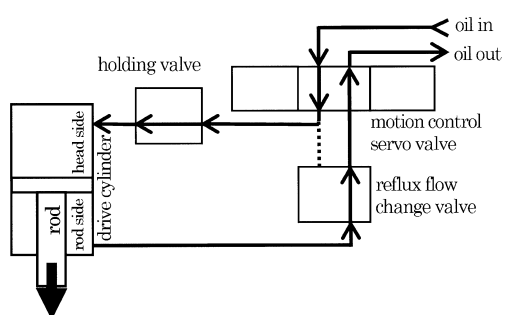

Fig. 30 Hydraulic flow when expanding a leg

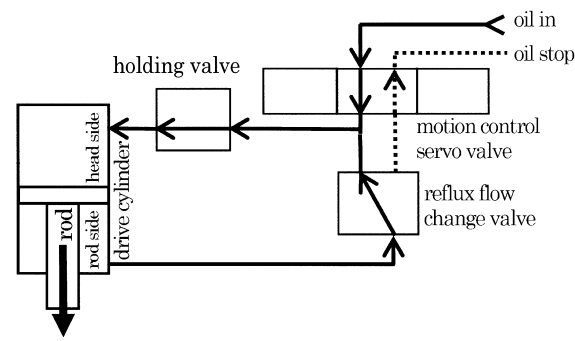

Fig. 31 Hydraulic flow when expanding a leg fastly with reflux flow principle

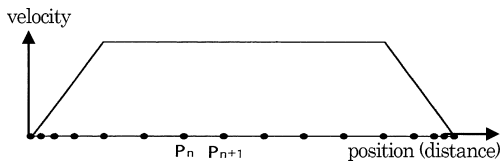

Fig. 32 To reduce inertial shock by trapezoidal speed control with continuous pass motion control method

5.3 油圧モーションコントロール

4.4 節で, 軟着地 , 加減速抑制の重要性を記したが, 加えて , すべての動作軸の加減速に際し, 慣性力による衝撃, 摇れを減 じるため，Fig. 32 に示す，工業用ロボット等で一般的な台形 加減速を加えている. 速度制御が必要となるが, 圧力変動（負 荷变動) 補償付き (速度) 比例弁はオープンループでもおおむ ね良好で, 使いやすいが, 応答性が悪く, 誤差が発生した場合 等での修正制御が難しく，採用しなかった。

Fig. 32 において，本機械では正確な位置決め，正確な速度制 御が行える，continuous pass 方式を，簡易型サーボ弁を使っ て実施した。

位置センサの情報から，ある位置 $P n$ に位置決めを行った後， サンプリングタイム $: T[\mathrm{~s}]$ の間に次の位置決め点 $P n+1$ へ距 離 : $L[\mathrm{~mm}]$ だけ移動した位置決めをさせる . 連続すると，例 えば，

$T: 20[\mathrm{~ms}]$ (本機械の実際値)， $L: 4[\mathrm{~mm}]$

では, 位置指令先, 移動対象は $200[\mathrm{~mm} / \mathrm{s}]$ で速度制御される。 本機械では，サーボ弁は位置決め用とし，ゲインを高く設定 し，高速応答性に期待した一種の ON/OFF 制御用に使ってい るが, 小刻みに指示を出しているので, ゲインは高くともわず かな応答遅れにより，動きは平滑化され，コギング感はなく滑 らかに動く.

位置制御ループが外周にあるので，弚の差分で行う速度制御 も，負荷変動の如何にかかわらず正確にできた .

上記 $T$ が一定で, 移動距離 : $L$ を制御して正確なモーション 
コントロールが可能で, Fig. 32 の台形加減速制御も容易である . なお, 連続して変わる指令位置に対し, 実際の位置が追従せ ず, 差が過大となった場合（過負荷や，アクチュエータ異常時 等) は, 全動作軸を停止, ロックする等の処置を取る .

\section{4 油圧制御系}

5.3 節のような制御を実現するために, 歩行系には全 8 軸 とも同じ簡易サーボ弁 (東京精密測器 (株) 304F-40L (max. $40[\mathrm{l} / \mathrm{min}], 21[\mathrm{MPa}]))$ を Fig. 33 の系の中で使用した . 304F$40 \mathrm{~L}$ は応答性 $(30[\mathrm{~Hz}] /-3[\mathrm{~dB}])$ で一般のサーボ弁 $(50[\mathrm{~Hz}]$ 以 上/ $-3[\mathrm{~dB}])$ に劣るが , 比例弁 (10〜20 $[\mathrm{Hz}]$ 以下) には優り， ゴミ耐性, 扱いやすさも良く, 低価格であった（ただし，各数 值とも 10 年以上前のもの).

速度指令があれば, 弚れを積分して位置指令とし，位置セン サ出力と比較して, 位置制御を行うことで速度を制御する。

速度を定めるため, サンプリングタイム間の変位分をリアル タイムに算出して, あるいは歩行制御部等から適値を指定して， 5.3 節の通り, サンプリングタイム間の移動距離 (5.3 節の $L$ に 相当）を定めることで速度も正確に制御している．

また, オペレータ指令のジョイスティック等のアナログ值を アナログのサーボ制御系に直に入れると, 厄介なドリフト問題

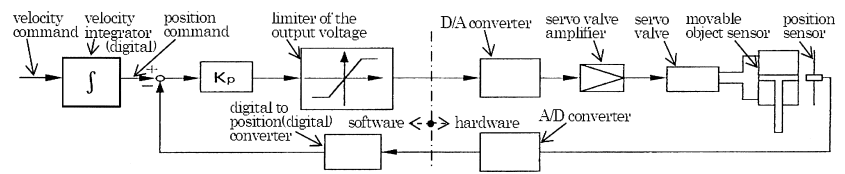

Fig. 33 Architecture of motion and positioning control

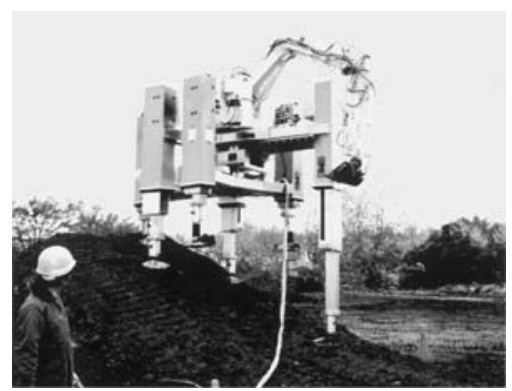

Fig. 34 Descending the slope of about 30 [deg], composed of soft soil

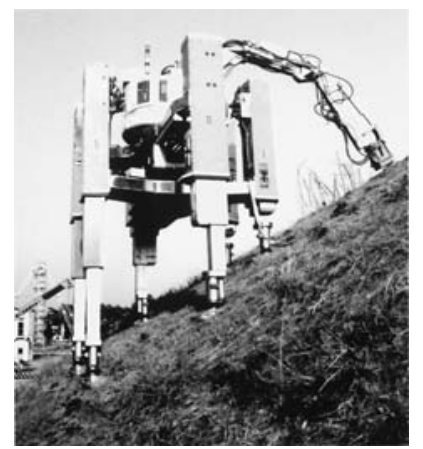

Fig. 35 Working with the cutting machine on the slope of about 30 [deg], after it works, it walks to the next place along contour line (see Fig. 6 \& Fig. 9)
が生じるが, デジタル変換した入力の中立付近にわずかな不感 帯を設け, 有意な入力時のみデジタル積分して上記と同樣な位 置制御による速度制御を行えば, 正確な動きが得られ, 待機状 態で指令值はサーボロックがかかり，ドリフトは発生しない． なお, Fig. 33 中の servo valve amplifier はサーボ弁の単なる $\mathrm{ON} / \mathrm{OFF}$ ドライバとしてしか使用していない. 作業用 6 軸（含 刏払い機) は, 高応答性や正確さは不要ゆえ, 手動比例弁を電 磁比例弁に替え, 遠隔操作化のみ行った .

\section{6. 試 作 と 試 験}

\section{1 各種動作試験}

具体的な歩行試験を色々な場所にて行った . Fig. 34 では約 $30^{\circ}$ の軟土猿丘斜面を下っている . Fig. 35 では斜面を等高線方 向に移動して全 6 脚を着地させ安定に作業を試験している . 脚 ストロークには余裕があり, Fig. 9 の通り $40^{\circ}$ の横斜面でも対 応できる . Fig. 36 , Fig. 37 は実際の山林地での歩行中のとこ ろ. 斜度は $20^{\circ} \sim 35^{\circ}$ で, 膨軟土㙥は潅木, 草に覆われ, 弚の 下には見え難い切株や岩が散在している．

\section{2 基本試験計測}

(1) 脚速度定速性確認

三つの支持脚に対し，低姿勢から高姿勢へ伸張（脚伸び長約 $200[\mathrm{~mm}] \rightarrow 1,800[\mathrm{~mm}])$ させた場合の脚伸び長 , 本機械の傾 斜の経過を計測した (Fig. 38) .なお， 3 脚で全体質量を持ち 上げての姿勢上昇だが , 伸張速度は約 $60[\mathrm{~mm} / \mathrm{s}]$ に抑えている (Fig. 30 の状態で) .

（2）脚引き上げ・軟着地制御確認

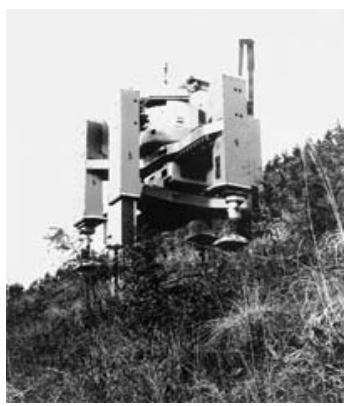

Fig. 36 The machine was driven and tested on practical forestry steep terrain

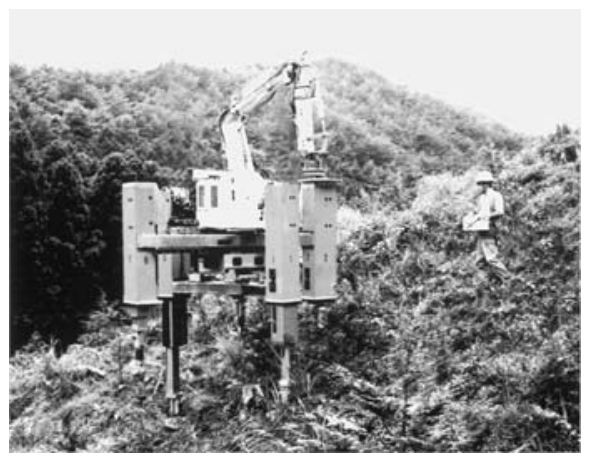

Fig. 37 In the area, the shrubs and the stumps lay much scattered and ground is soft soil 


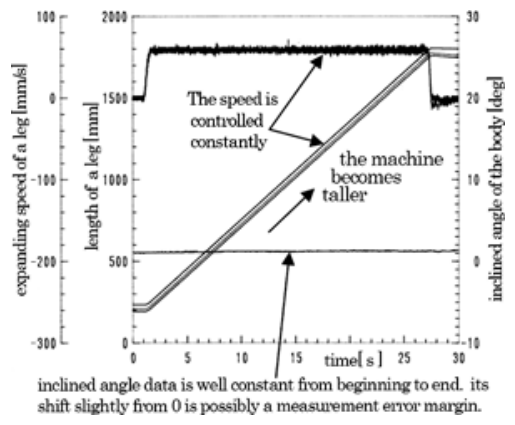

Fig. 38 Stability of the velocity of the legs and levelness

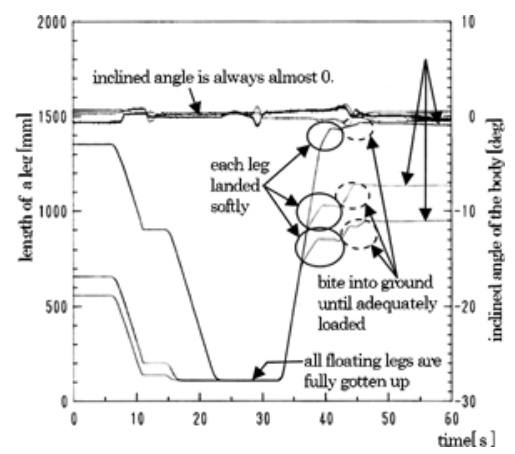

Fig. 39 Appearance of soft landing of legs

Fig. 39 において, 開始時に, 三つの脚の脚伸び長が約 $550[\mathrm{~mm}], 650[\mathrm{~mm}], 1,350[\mathrm{~mm}]$ となる斜面にいることが分 かる.

約 7 秒後, 3 脚の引き上げを開始している. 途中，他 3 支持 脚の地崩れがあって機体がわずかに傾いたので傾斜補正が行わ れ, 脚引き上げが若干停止したが, 補正後から 23 秒までに全 脚か脚伸び長約 $100[\mathrm{~mm}]$ に引き上げ完了している . 引き上げ 速度は約 $105[\mathrm{~mm} / \mathrm{s}]$.

なお，各起動/停止時の加減速がなまっているのは, 5.3 節の Fig. 32 の台形加減速による慣性衝撃の低減によるものである .

オペレータによる方向操作後の 33 秒後からまず $220[\mathrm{~mm} / \mathrm{s}]$ で 3 脚が同時高速降下され (Fig. 19の (1)，Fig. 31 (還流増速) の状態)，以降の各脚がおのおのの高さの地面近くで Fig. 19 の 制御により，約 $50[\mathrm{~mm} / \mathrm{s}]$ に減じて軟着地していることが示さ れている. わずかな停止後, 続けて低速伸長が行われているの は, 土壌か軟らかく，着地後に適当な荷重支持とならず，なる までの「踏み固め」の実行を示している (4.4 節の Fig. 19 およ び Fig. 20 (4) 参照) .

(3) 傾斜補正機能応答性

本機械では, 山林土猿等で起こり得る，地崩れ等への対応と して，リアルタイム傾斜補正機能を組み込んでいる．

Fig. 40 にて , length of the 3 supporting legs の曲線に示 す長さの脚で , Fig. 40 の上方のように pitch , roll を融合した over all の傾斜角が最大約 $10^{\circ}$ になる途中から，沈んでいない 側の脚を縮め，沈んだ側の脚を伸長して補正動作を行っている．

Fig. 40 の試験結果では，傾斜が大きくなった時点から，弚の 収束までに，約 2 秒を要しており，十分な応答性とは言えない． 本機械では動力源の出力が小さいが , 今後のパワーアップほか

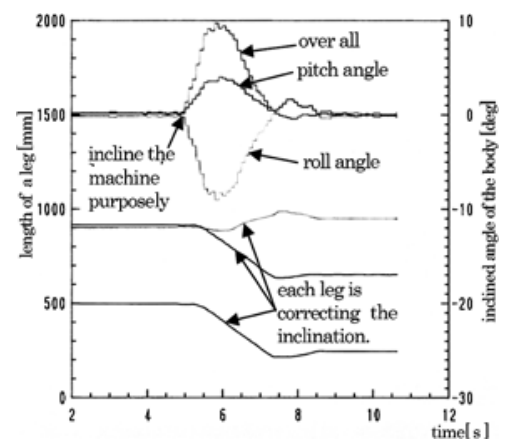

Fig. 40 Response that corrects inclination

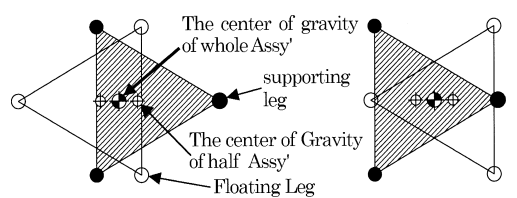

Fig. 41 The position, height and motion of the center of gravity is always measured to avoid rollover

改良により，実用的な転倒回避が可能であることが予想できる． ただし，現状でも，一歩一歩での膨軟土壌沈下に応じる傾斜 補正動作は機体をよく安定させ，安心感を与え，有効であった．

\section{3 実地試験}

実地にて各種歩行試験を行った．木は伐採・収穫されており， 兴の後に植樹 (高さ $1[\mathrm{~m}]$ 程度) がおおむね $1.8[\mathrm{~m}]$ の格子状に 植えられていた .ただし, 最大直径数 $\mathrm{cm}$ 程度の㴶木, 杂隹草, 枯 れ枝等の堆積があり，見えない切り株も多い．人が歩くにはき つかった .

斜度はおおむね $20^{\circ} \sim 30^{\circ}$ 程度であるが, 局地的には $35^{\circ} \sim 40^{\circ}$ に達する場所は散在した . ただし，迂回しての登降坂はできた .

Fig. 36 , Fig. 37 の実地では, 潅木 , 雑草等が茂っていたので， 4.4 節の Fig. 19 の脚の自動的な軟着地制御, 光して, 4.5 節の 脚先接地部の検討などは有効であり，危険はなく，光の検討·設 計の妥当性か証明でき，大変有意義であった

ただし , 散在する切株上で , 脚がわずかなひつかかりで立って しまった場合が危なく，結果， 4.3 節 (1) の Fig. $16 \rightarrow$ Fig. 17 と同樣のことが起きたが, 弚れらによる損傷等の支障はなく, 傾 いても傾斜補正機能が作動して，危険な状態に至らなかった .

ただ，乥こで，いわゆる安定三角形に対する重心の安定余裕 が作業アーム他の状態次第で少なくなることがあることが分かっ た. 光のため, 歩行中, Fig. 41 に示す通り, 3 支持脚の接地 点で構成される三角形の中の重心位置の余裕度と，重心の高さ， 乥して重心の水平速度と加速度は常に計測し, 転倒回避, 安定 性確保, 乥して不安定状態になった場合の警告, 操作制限を行 う. 4.4 節の Fig. 21 の水平動作の速度, 加速度の姿勢高に応じ た制限とともに，本機械の歩行安全性を高めている．

\section{7. ま と め}

今後, 必要な改善として, 高速, 高応答化が挙げられる。

本機械は, 光の駆動源に市販ミニショベルのものを流用した . 主に開発期間と工数の低減が理由であった．弚の機関出力約 $11[\mathrm{~kW}]$ は, 試験を通し，4[t] の歩行機械用としては非力であっ 
栄二 内山研史玉田守

た. 現実的には $40[\mathrm{~kW}]$ 程度の現状の数倍の出力の機関とポンプ を使えば, 歩行速度は 2 倍以上に高速化できる.さらに，6.2 節 (3) で触れた傾斜補正機能を本件のような足場の悪い歩行時の 転倒回避機能として実用化が見込め, 意義は大きい .

オートバイの小型高出力のエンジンで, HST (Hydro Static Transmission) 等を活用し, 各軸独立の高速可変速機能を有し， 本機械等と比べ, 速く, かつ高効率に歩行移動する機械の開発 事例 [17] [18] もあるので参考としたい .

先にも述べたようにこなれた機構要素, 比較的簡単・確実な 制御装置を組み合わせて完成されている特長を活かし，従来の 機械が入り難かった場所での普及を念頭に, 改良機の開発を進 めたいと考える.

謝 辞 本開発は, 林野庁の補助事業である「育林用林業機械 開発事業」により行われ，1996 年度 (平成 8 年度) に完了した。

林野庁, (社) 林業機械化協会, 関係大学, (独) 森林総合研究 所，弚の他開発支援者各位に感謝する.

また，何らかの事情で連絡が取れず, 本論文への意見をもら えなかったが, 本機械の開発を強力に推進した，当時の，(社) 林業機械化協会の荒井宏常務理事にも感謝する.

\section{参 考 文 献}

[1] 小谷内範穂, 安達弘典, 中野栄二: “自立形 6 脚移動ロボット MELCRAB-2", 第 3 回知能移動ロボットシンポジウム予稿集 ,pp.2530, 1986.

[ 2 ] 岩崎峯夫, 秋園純一, 梅谷登志文: “歩行式水中調査ロボットの開発”, 第 3 回知能移動ロボットシンポジウム, pp.31-36, 1986.

[ 3 ] 妻木俊道 : “6 脚歩行機械の開発”, 日本機械学会ロボティクス・メカ トロニクス講演会'93 講演論文集 , pp.336-339, 1993.
[4] 妻木俊道, 阿部誠一郎, 千葉健吉 : “6 脚歩行機械 Landmaster3 の 開発”，日本ロボット学会誌，vol.24, no.7, pp.851-860, 2006.

[5] Y. Ishino, T. Naruse, T. Sawano and N. Honma: "Walking robot for underwater construction," Advanced Robotics (ICAR '83), pp. 107-114, 1983.

[6] J.E. Bares and W.L. Whittaker: "Walking robot with a circulating gait," IEEE International Workshop on Intelligent Robots and Systems IROS'90, pp.809-816, 1990.

[ 7 ] PLUSTECH Oy, Inc. (Finland)'s catalogue: "GOING FOR A WALK NATURALLY," 1995.

[8] John Deere 社: “Timberjack Walking Machine（林業用ハーベス タ搭載 6 脚歩行ロボット)", パンフレット，1998.

[9] 妻木俊道, 小林洋司, 中野栄二, 福田章史, 荒井宏: “急傾斜山林地 移動用大型 6 脚歩行機械の開発”, 日本機械学会ロボティクス・メカ トロニクス講演会'98 講演論文集 (CD-ROM) , 2CIII 1-8, 1998.

[10] S. Hirose: "A study of Design and Control of a Quadruped Walking Vehicle“, Int. J. Robotics Research, 3-2, pp.113-133, 1984.

[11] 広瀬茂男, 梅谷陽二：“歩行機械の脚形態と移動特性”, バイオメカ二 ズム—動体の機構と制御一, pp.242-250, 1980.

[12] 道路運送車両の保安基準第 2 章, 自動車の保安基準第 2 条, http:// law.e-gov.go.jp:80/htmldata/S26/S26F03901000067.html

[13] 中嶋秀朗, 中野栄二: “脚車輪分離型ロボットの大不整地適応歩容 (第 5 報，総合歩容編)”，日本機械学会論文集 (C 編), vol.72, no.721, pp.272-279, 2006.

[14] 不整地歩行機械, 登録番号 2535568 (平成 9 年実用新案登録)，1997。

[15] 静歩行ロボットの制御方式, 登録番号 3442996 (平成 15 年特許登 録)，2003.

[16] 不二越油圧研究グループ著: 知りたい油圧 (基礎編, 応用編, 実際編, vol.3 (旧版))，ジャパンマシニスト社刊，1983 発行版.

[17] D.R. Pugh, M.R. Patterson and K.J. Waldron: "Technical Description of Adaptive Suspension Vehicle," The International Journal of Robotics Research, vol.9, no.2, pp.24-42, 1990.

[18] S.-M. Song and K.J. Waldron: Machines That Walk:The Adaptive Suspension Vehicle. The MIT Press, 1988.

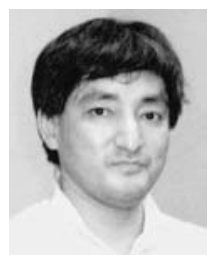

妻木俊道 ( Toshimichi Tsumaki)

1983 年 3 月東京工業大学機械物理工学科卒業, 同 年 4 月三菱重工業 (株) 入社. 相模原製作所 (現:汎 用機・特車事業本部) 生産技術課配属 . コンピュー タ, シーケンスコントローラによる過給器ほか量産 品無人生産システムの開発, 施工に従事 . 各種社内 表彰受賞. 1990 年より屋外用不整地移動ロボット， 遠隔制御技術，光して自律移動ロボット制御部の研究・開発に従事。 現在，技術統括部門において，ハイブリッド駆動技術，2 次電池など の新技術の調査, 研究を行う. 新製品担当主席技師. 1992 年第 3 回 日本ロボット学会技術賞受賞.

(日本ロボット学会正会員)

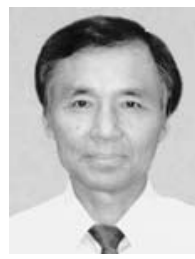

中野栄二( Eiji Nakano)

1970 年東京大学大学院工学研究科博士課程修了. 同 年通産省工業技術院機械技術研究所研究員. 1987 年東北大学工学部教授. 1993 年東北大学大学院情 報科学研究科教授. 2005 年千葉工業大学教授 (現 職) . 1976 1977 年米国スタンフォード大学人工知 能研究所客員研究員.福祉介護ロボッ卜, 不整地移 動ロボット, 建設ロボット, メッセンジャロボットなどの研究開発に 従事. 日本ロボット学会論文賞, 科学技術庁長官賞, 日本ロボット工 業会貢献賞ほか受賞 .

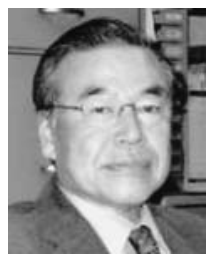

小林洋司 ( Hiroshi Kobayashi)

東京大学名誉教授.日本林業技士会, 首席研究員 (農 学博士). 1966 年 3 月東京大学農学部卒業, 1969 年農林省林業試験場研究員, 1977 年宇都宮大学助 教授, 1987 年東京大学助教授, 1991 年東京大学教 授，2006 年 6 月東京大学名誉教授，2007 年 5 月 より現職。前森林利用学会長, 元 : 日本林学会常務 理事, 現 : 日本大学, 東京農業大学非常勤講師, 森林利用学研究に従 事, 特に林業機械, 林道網の研究を行う. 1987 年日本林学会賞受賞.

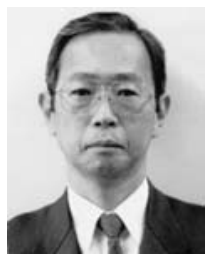

内山研史 ( Kenji Uchiyama) 1971 年 3 月三重大学林学科卒業, 同年 4 月農林水 産省林野庁入庁. 長野営林局坂下営林署, 鹿児島県 林務水産部, 林野庁技術開発推進室, 北海道森林管 理局等に勤務，国有林野事業の管理経営，民有林行 政，林業機械の開発改良等に従事. 2000 年から社 団法人林業機械化協会において林業機械の開発改良

に従事

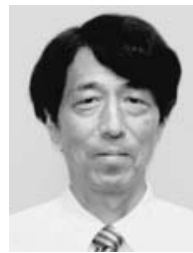

玉田 守 ( Mamoru Tamada)

1975 年千葉工業大学工学部電子工学科卒業. 1985 年より特殊車両や各種屋外用移動ロボットの特殊環 境電装設計を行い, 2003 年から東京工業大学広瀬・ 福島研地雷探査ロボットの電装設計・開発に従事 . 現在, (有) イーストドライブ取締役. 